\title{
Oxygenated compounds in aged biomass burning plumes over the Eastern Mediterranean: evidence for strong secondary production of methanol and acetone
}

\author{
R. Holzinger ${ }^{1, *}$, J. Williams ${ }^{1}$, G. Salisbury ${ }^{1}$, T. Klüpfel ${ }^{1}$, M. de Reus ${ }^{1}$, M. Traub ${ }^{1}$, P. J. Crutzen ${ }^{1}$, and J. Lelieveld ${ }^{1}$ \\ ${ }^{1}$ Max-Planck-Institut für Chemie, Postfach 3060, 55020 Mainz, Germany \\ * now at: University of California at Berkeley, Dept. Environm. Sci. Policy \& Management, Berkeley, CA 94720 USA
}

Received: 5 August 2004 - Published in Atmos. Chem. Phys. Discuss.: 7 October 2004

Revised: 13 December 2004 - Accepted: 28 December 2004 - Published: 17 January 2005

\begin{abstract}
Airborne measurements of acetone, methanol, PAN, acetonitrile (by Proton Transfer Reaction Mass Spectrometry), and CO (by Tunable Diode Laser Absorption Spectroscopy) have been performed during the Mediterranean Intensive Oxidants Study (MINOS August 2001). We have identified ten biomass burning plumes from strongly elevated acetonitrile mixing ratios. The characteristic biomass burning signatures obtained from these plumes reveal secondary production of acetone and methanol, while $\mathrm{CO}$ photochemically declines in the plumes. Mean excess mixing ratios - normalized to CO - of $1.8 \%, 0.20 \%, 3.8 \%$, and $0.65 \%$ for acetone, acetonitrile, methanol, and PAN, respectively, were found. By scaling to an assumed global annual source of 663-807 Tg CO, biomass burning emissions of 25-31 and $29-35 \mathrm{Tg} / \mathrm{yr}$ for acetone and methanol are estimated, respectively. Our measurements suggest that the present biomass burning contributions of acetone and methanol are significantly underestimated due to the neglect of secondary formation within the plume. Median acetonitrile mixing ratios throughout the troposphere were around $150 \mathrm{pmol} / \mathrm{mol}$, in accord with current biomass burning inventories and an atmospheric lifetime of $\sim 6$ months.
\end{abstract}

\section{Introduction}

Biomass burning is among the largest anthropogenic air pollution sources, and it impacts the atmosphere on a global scale. The amount of biomass burned each year is estimated to be of order $8600 \mathrm{Tg}(+/-50 \%$, Andreae and Merlet, 2001). Along with the emission of large quantities of $\mathrm{CO}_{2}, \mathrm{CO}$, organic aerosols, and black carbon a myriad of other organic compounds are emitted at lower but nevertheless significant

Correspondence to: R. Holzinger

(holzing@ nature.berkeley.edu) levels (Yokelson et al., 1999; Goode et al., 2000; Andreae and Merlet, 2001; Holzinger et al., 1999; Simoneit, 2002).

Trace gases like acetone, carbon monoxide, methanol and peroxyacetyl-nitrate (PAN) play important roles in atmospheric chemistry, and all are directly emitted and/or produced in biomass burning plumes. Acetone is an important source of $\mathrm{HO}_{\mathrm{x}}$ radicals (Singh et al., 1995) in the upper troposphere. Carbon monoxide together with methane controls the atmosphere's reactivity in remote areas. Methanol is one of the most significant organic compounds in the atmosphere, having an annual atmospheric carbon turnover that is exceeded only by methane and isoprene. The photochemical product PAN is relatively stable to photolysis and $\mathrm{HO}$ oxidation in the free troposphere, but decomposes rapidly at temperatures above $15-20^{\circ} \mathrm{C}$. In this way PAN and other organic-nitrates have the potential to sequester, transport and release nitrogen oxides $\left(\mathrm{NO}_{\mathrm{x}}\right)$ at great distances from the source.

In this study we investigate aged biomass burning plumes observed over the Mediterranean Sea. Using acetonitrile as a marker for biomass burning we found higher levels of acetone and methanol than in fresh or experimental fire plumes. Our results suggest that biomass burning is a significant source of acetone, methanol and PAN.

\section{Experimental}

The Mediterranean Intensive Oxidant Study (MINOS) was conducted in August 2001 (Lelieveld et al., 2002). 14 measurement flights up to altitudes of $13 \mathrm{~km}$ were performed with a twinjet Falcon aircraft operated by DLR (German Aerospace Centre), from Heraklion airport, Crete $\left(35^{\circ} \mathrm{N}, 25^{\circ} \mathrm{E}\right)$; for details about MINOS visit http://www. mpch-mainz.mpg.de/ reus/minos/. Carbon monoxide was measured by Tunable Diode Laser Absorption Spectroscopy

(C) 2005 Author(s). This work is licensed under a Creative Commons License. 


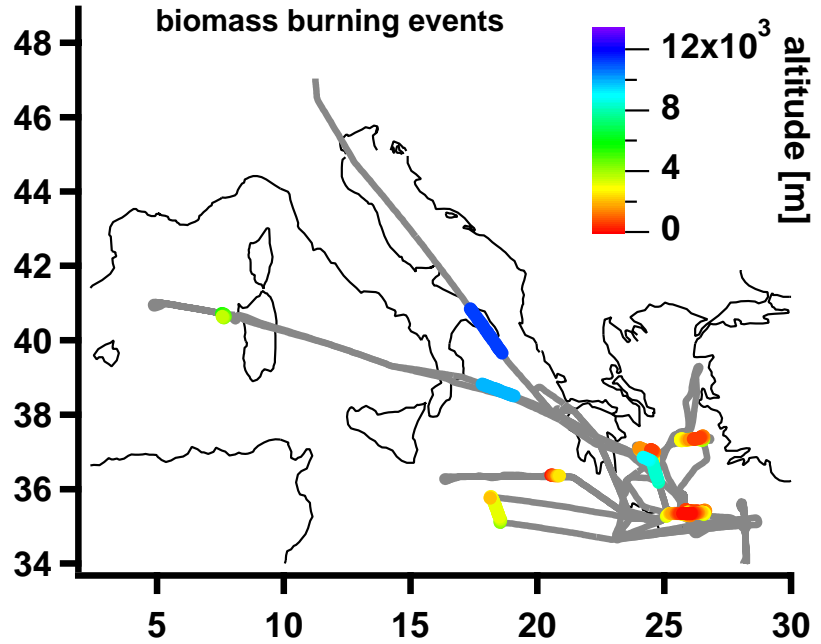

Fig. 1. Flight tracks and location of biomass burning plumes.

(TDLAS) with an accuracy of $1 \%$ and a precision of $1.5 \mathrm{nmol} / \mathrm{mol}$ (Wienhold et al., 1998). Acetone, acetonitrile, methanol and PAN were measured by Proton-TransferReaction Mass Spectrometry (PTR-MS). Like most VOCs with proton affinities higher than water, acetone, acetonitrile and methanol are detected at their protonated masses 59, 42, and $33 \mathrm{amu}$, respectively (Lindinger et al., 1998). Protonated PAN, however, reacts with water to produce $\mathrm{CH}_{3} \mathrm{C}(\mathrm{O}) \mathrm{OOHH}^{+}$at mass 77 (Hansel and Wisthaler, 2000). The collision energies between ions and molecules in the PTR-MS were minimised in order to prevent sensitivity loss due to the fragmentation of protonated PAN. Typical values for the ratio $\mathrm{E} / \mathrm{N}$ were 90 Townsend $\left(\mathrm{Td} ; 1 \mathrm{Td}=10^{-17} \mathrm{~V} \mathrm{~cm}^{2}\right)$. Comparison with a second PTR-MS operated under standard conditions (120 Td) by the University of Utrecht showed good agreement between the two instruments (de Gouw et al., 2003). The instrument background signal was measured every few minutes by converting VOCs efficiently to $\mathrm{CO}_{2}$ and water in a heated stainless steel tube $\left(350^{\circ} \mathrm{C}\right)$ filled with a platinum catalyst. Based on atmospheric chemistry considerations (Williams et al., 2001) and from a GC-PTRMS analysis of several Teflon bags filled in-flight (de Gouw et al., 2003) we are confident that at masses 33, 42 and 59 no significant contributions were detected $(>10 \%)$ from molecules other than methanol, acetonitrile and acetone, respectively. Potential interference from other molecules at mass 77 (PAN) was assessed by applying an additional thermal converter every few minutes. The converter was operated at $120^{\circ} \mathrm{C}$ and thermally destroyed PAN at this temperature; other compounds were found to pass through the converter without losses. Using the PTR-MS technique trace gas concentrations can be calculated according to the relation $\left[\mathrm{VOC} \cdot \mathrm{H}^{+}\right] \approx\left[\mathrm{H}_{3} \mathrm{O}^{+}\right][\mathrm{VOC}] \mathrm{k}_{\mathrm{VOC}} t$, where $t$ is the reaction time and $\mathrm{kVOC}_{\mathrm{V}}$ is the reaction rate constant for the proton transfer from $\mathrm{H}_{3} \mathrm{O}^{+}$to compound VOC. Note that all param- eters in this relation are known and no in-flight calibration was needed. However, to ensure that all relevant parameters, namely the reaction rate constants, reaction time and transmission of the mass spectrometer were accounted for correctly, we cross checked the applied calculations and corrections by measuring a gravimetrically prepared calibration gas standard (Apel-Riemer Enviromental Inc) with a certified accuracy better than $5 \%$ for methanol, acetone and acetonitrile. These compounds were calibrated against the gas standard by fine-tuning parameters like reaction rate constants and transmission. In the case of PAN it is difficult to calculate concentrations because more than one ion-molecule reaction is involved. In laboratory studies we investigated how the detection sensitivity of PAN is influenced by parameters such as humidity and pressure. The PTR-MS signal attributed to PAN was calibrated using a commercial GC-ECD (Meteo-Consult) which was calibrated using a synthesised PAN standard, the concentration of which was determined by measurements of NO after the PAN was passed through an $\mathrm{NO}_{\mathrm{y}}$ converter. The synthesis and calibration method is described in detail elsewhere (Williams et al., 2000). The overall accuracy for all compounds measured with PTR-MS is better than $20 \%$ (40\% for PAN), with reservations regarding possible interference to the signal at m77 coming from molecules other than PAN.

The specific masses of methanol, acetonitrile, acetone, and PAN have been integrated for 2, 5, 2, and $5 \mathrm{sec}$, respectively. One cycle was completed in $\sim 20 \mathrm{sec}$, wich also included mnonitoring of the primary ion signal (4-6 million counts per second) and several engeneering parameters. The precision of the PTR-MS data is dependent on integration time, background signal and mixing ratio. Detection limits, determined as $3 \sigma$ above background, for acetone, acetonitrile, methanol and PAN were 100, 20, 500, $50 \mathrm{pmol} / \mathrm{mol}$ respectively; and typical values for the precision at levels of 50, 500 and $2000 \mathrm{pmol} / \mathrm{mol}$ were as follows: $30,10,5 \%$ for acetonitrile; $-, 25,10 \%$ for acetone; $-, 70,20 \%$ for methanol; and $60,20,10 \%$ for PAN, respectively.

\section{Results and discussion}

\subsection{Biomass burning plumes}

During the MINOS campaign we identified ten biomass burning plumes at altitudes between 1 and over $11 \mathrm{~km}$ at various locations over the eastern Mediterranean region (Fig. 1). Plumes were identified by significant peaks in the acetonitrile volume mixing ratio; i.e. the difference in concentration between peak and neighbouring points exceeded at least three times the standard deviation of the neighbouring points. From the ten plumes, six (i.e. those below $2 \mathrm{~km}$ and east of $24^{\circ} \mathrm{E}$ ) are likely to originate from agricultural burning, a great deal of which was occurring in Eastern Europe at the time of the MINOS campaign. According to a trajectory 


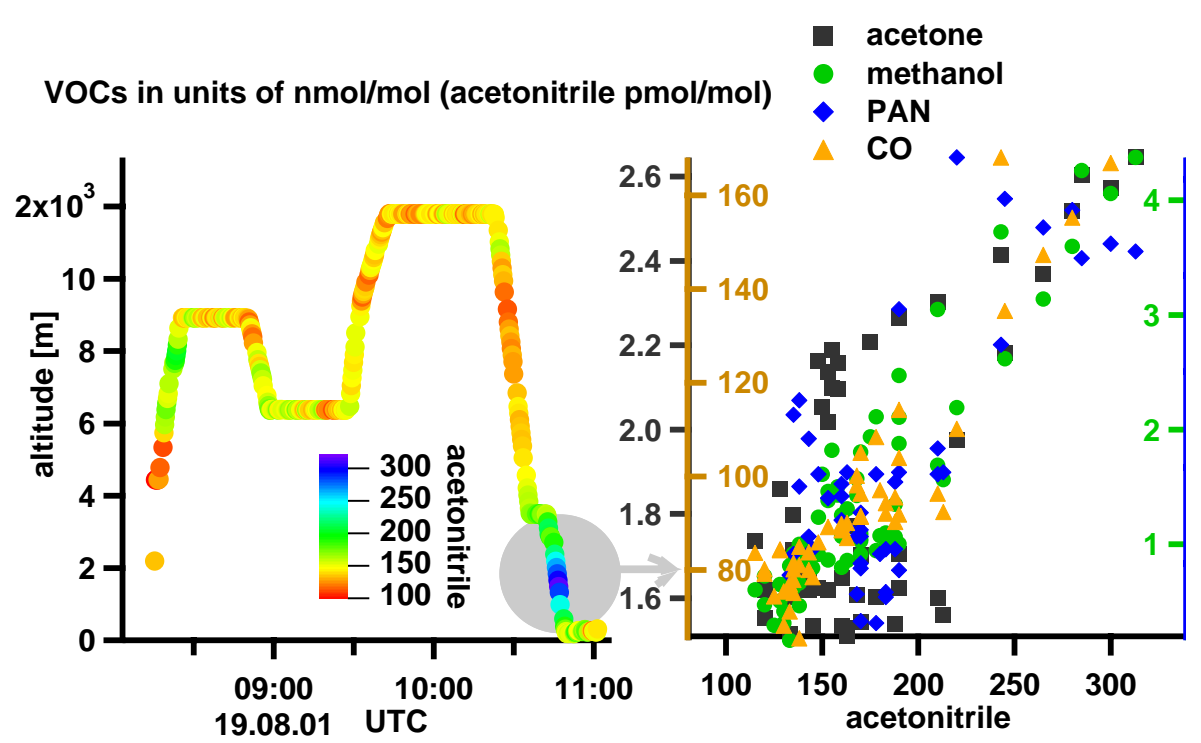

Fig. 2. An example biomass burning signature. Usually good correlation of acetonitrile with CO, acetone, methanol and PAN was observed in biomass burning plumes.

Table 1. Time, position and NEMRs of biomass burning plumes encountered during MINOS.

\begin{tabular}{|c|c|c|c|c|c|c|c|}
\hline Time & Position & $\mathrm{Alt}^{a}$ & acetonitrile $^{b}$ & Methanol $^{c}$ & acetone $^{c}$ & $\mathrm{PAN}^{c}$ & $\mathrm{CO}^{c}$ \\
\hline 14.08. 06:21 & $37.0 \mathrm{~N}, 24.3 \mathrm{E}$ & 1.9 & 250 & 26.4 & 2.1 & -1.1 & 476 \\
\hline 14.08. 12:55 & $37.3 \mathrm{~N}, 26.2 \mathrm{E}$ & 3.7 & 203 & 24.1 & 14.1 & 5.5 & 733 \\
\hline 14.08. 13:14 & $37.4 \mathrm{~N}, 26.1 \mathrm{E}$ & 1.7 & 206 & 20.7 & 16.8 & 6.1 & 792 \\
\hline 17.08. $14: 15$ & $35.4 \mathrm{~N}, 26.1 \mathrm{E}$ & 2.0 & 192 & 24.9 & 19.2 & 2.0 & 907 \\
\hline 19.08. 10:46 & $35.3 \mathrm{~N}, 25.9 \mathrm{E}$ & 1.9 & 243 & 18.7 & 8.6 & 1.7 & 477 \\
\hline 19.08. 15:44 & $36.4 \mathrm{~N}, 20.7 \mathrm{E}$ & 1.3 & 211 & 17.2 & 10.0 & 6.5 & n.m. \\
\hline 19.08. 16:29 & $35.3 \mathrm{~N}, 25.4 \mathrm{E}$ & 1.8 & 237 & 12.4 & 4.6 & 0.8 & 556 \\
\hline $22.08 .05: 52$ & $38.7 \mathrm{~N}, 18.4 \mathrm{E}$ & 9.9 & 180 & 13.7 & 8.7 & 3.2 & 160 \\
\hline 22.08. 10:32 & $40.7 \mathrm{~N}, 7.6 \mathrm{E}$ & 4.6 & 155 & 14.1 & 9.2 & 5.8 & 381 \\
\hline $24.08 .08: 17$ & $40.2 \mathrm{~N}, 18.0 \mathrm{E}$ & 11.1 & 214 & 24.5 & 12.6 & 3.4 & 467 \\
\hline \multicolumn{4}{|c|}{ geometric mean ${ }^{d}$} & 19.0 & 9.1 & 3.2 & 498 \\
\hline
\end{tabular}

a Altitude in $\mathrm{km}$.

${ }^{b}$ Average volume mixing ratio of acetonitrile in the plume in units of $\mathrm{pmol} / \mathrm{mol}$.

${ }^{c}$ Normalized excess mixing ratio (NEMR) in units of $\mathrm{mol} / \mathrm{mol}$.

${ }^{d}$ Geometric mean of individual NEMRs; negative values have been omitted.

analysis the age of these plumes was about 2-3 days (Traub et al., 2003). It was not possible to identify the source region of the other plumes.

A case study of a biomass burning plume encountered towards the end of flight 10 (19 August 2001; 08:1511:10 UTC (=Local time $-3 \mathrm{~h}$ )) is presented in Fig. 2. The left-hand chart depicts cruising altitude and acetonitrile volume mixing ratios. The biomass burning plume is highlighted with a grey circle; in this region a good correlation occurs between acetonitrile and acetone $\left(n=70, \mathrm{r}^{2}=0.85\right), \mathrm{CO}$ $\left(n=54, r^{2}=0.69\right)$, methanol $\left(n=70, r^{2}=0.69\right)$, and PAN $(n=60$, $\left.\mathrm{r}^{2}=0.40\right)$ (right-hand chart).
The time, position, and altitude of all biomass burning plumes is given in Table 1, together with acetonitrile mixing ratios and normalized excess mixing ratios (NEMR) of acetone, $\mathrm{CO}$, methanol, and PAN; the latter were obtained as follows: excess mixing ratios (EMR) were calculated by subtracting the mixing ratios just before or after a biomass burning plume from in-plume values. Note that for each plume a different background was used, which reflected atmospheric concentrations outside the plume. In a second step the EMRs were normalized by division by the EMR of acetonitrile. A mean NEMR was calculated for each compound by forming the geometric mean from all NEMRs of individual biomass 


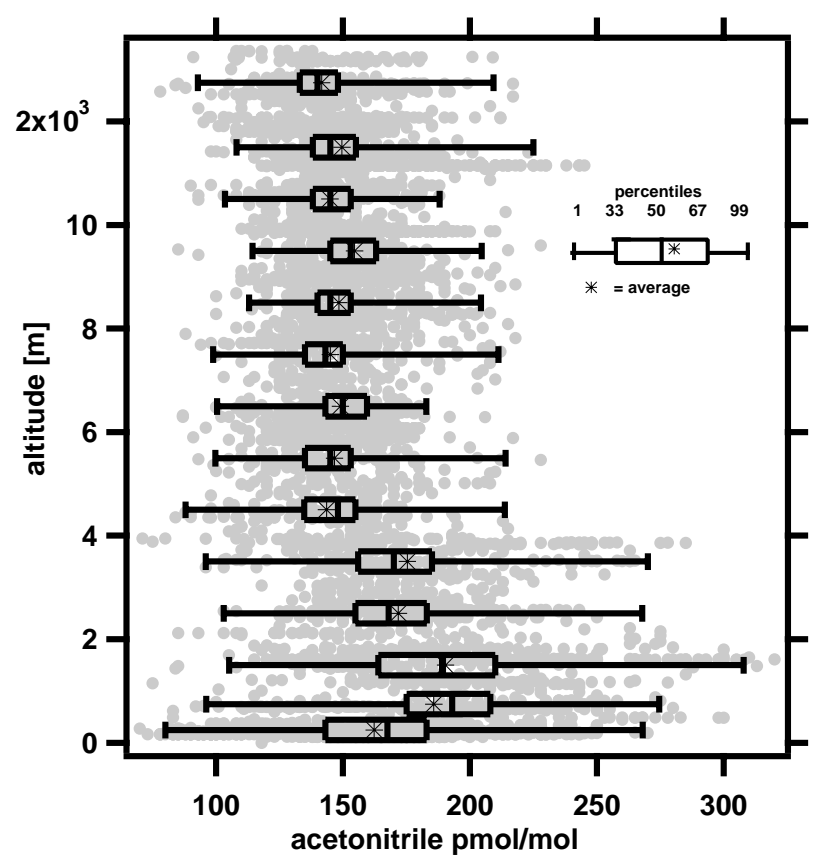

Fig. 3. Height profile of acetonitrile with a statistical evaluation of the data points at different altitudes.

burning events (Table 1). To avoid overestimation because of outliers we favoured the geometric mean.

In a fresh biomass burning plume the NEMR is equivalent to the emission ratio (ER), however, NEMRs obtained here may be different because the plumes were aged and organic species might have been produced or destroyed. In Table 2 NEMRs based on CO are shown together with emission ratios from previous laboratory and field studies. Emission ratios of $\sim 1.2 \mathrm{mmol}$ acetonitrile per mol CO have been consistently reported from several laboratory and field experiments. Significantly higher emission ratios have been reported from Indonesian fuels (Christian et al., 2003) of which the nitrogen content was higher than in fuels from other regions; the same was assumed to be the case in the single fire study reported by Jost et al. (2003).

During the MINOS campaign we observed a mean NEMR of $2.0 \mathrm{mmol}$ acetonitrile per mol CO which is $\sim 50 \%$ higher than most reported values from other studies (Table 2). This may reflect a higher nitrogen content of the fuels causing the observed plumes. Another plausible explanation for this discrepancy is photochemical degradation of CO since the plumes encountered over the Eastern Mediterranean were considerably aged. On average $24 \mathrm{~h}$ mean concentrations of $\mathrm{HO}$ of $4.5 \times 10^{6}$ molecules $/ \mathrm{cm}^{3}$ were measured at the Finokalia ground station in Crete during the MINOS campaign (Berresheim et al., 2003). If such high values are representative for the region, $24 \%$ of the CO in a biomass burning plume would be removed within the assumed travel time from the source region northeast of the Black sea (3 days), whereas mixing ratios of acetonitrile would not be reduced significantly on this timescale. The chemical CO loss is partly balanced by secondary $\mathrm{CO}$ production; however, the sum of compounds (based on Andreae and Merlet, 2001) that might form secondary $\mathrm{CO}$ is about an order of magnitude lower. If the NEMR is corrected for $24 \%$ chemical CO loss the obtained value of $1.5 \mathrm{mmol} / \mathrm{mol}$ is close to what is reported for fresh biomass burning emissions.

The NEMRs of methanol and acetone found during MINOS (Table 2) are significantly higher than what was found in previous studies; methanol is enhanced by a factor of 2 6 , and acetone by a factor of $2-14$. Photochemical degradation of $\mathrm{CO}$ can by no means explain these discrepancies, as the lifetimes of both acetone and methanol are shorter than that of CO. Therefore our results strongly indicate secondary production of methanol and acetone in biomass burning plumes and support recent measurements by Jost et al. (2003) who found fast chemical production of acetone in a fresh biomass burning plume over Namibia. By scaling to an assumed annual carbon monoxide emission of 663-807 Tg (Bergamaschi et al., 2000) our results suggest a global biomass burning source of $25-31 \mathrm{Tg}$ and $29-35 \mathrm{Tg}$ for acetone and methanol, respectively. Comparing these numbers with global budget estimates for acetone $(95 \mathrm{Tg} / \mathrm{yr}$, Jacob et al., 2002) and methanol (345 Tg/yr, Heikes et al., 2002 ) the biomass burning contribution may be $\sim 25 \%$ and $\sim 10 \%$, respectively. Most recently, Singh et al. (2004) estimated annual biomass burning sources of 9 and $11 \mathrm{Tg} / \mathrm{yr}$ for acetone and methanol, respectively. Our results imply that oxidation processes in the plume are quite efficient, and that secondary production dominates over primary emission for both compounds; the mechanism for this oxidation, however, remains unclear.

Salisbury et al. (2003) compared acetone and methanol measurements performed at Finokalia station, Crete, August 2001, with the modelled concentrations of the MATCHMPIC (Model of Atmospheric Chemistry and Transport, Lawrence et al., 2002). Although the modelled and measured acetone and methanol were well correlated, the model significantly underestimated the concentrations. Part of this discrepancy can probably be resolved by initialising the model with higher production factors as is suggested by our measurements.

As far as we know, there are no studies assessing a production rate of PAN from biomass burning, although it has been reported as a secondary product in biomass burning plumes (Mauzerall et al., 1998; Talbot et al., 1999; Singh et al., 2004). Considering the thermolability of this compound, however, we refrain from a global extrapolation for PAN production in biomass burning plumes (which would be of the order of $29-35 \mathrm{Tg} / \mathrm{yr}$ ). 
Table 2. Emission ratios and NEMRs based on CO (mmolVOC/molCO).

\begin{tabular}{|c|c|c|c|c|}
\hline Fuel Type & methanol & acetonitrile & acetone & PAN \\
\hline \multicolumn{5}{|l|}{ this study 1} \\
\hline not identified & 38 & 2.0 & 18 & 6.5 \\
\hline \multicolumn{5}{|l|}{ Holzinger et al. (1999), lab study } \\
\hline Savanna grass & 6.4 & 1.3 & 5.4 & \\
\hline \multicolumn{5}{|l|}{ Christian et al. (2003), lab study } \\
\hline African savanna fuels & 15 & 1.2 & 1.3 & \\
\hline Indonesian fuels & 24 & 6.5 & 4.6 & \\
\hline \multicolumn{5}{|l|}{ Jost et al. (2003), field study } \\
\hline African savanna fire & & $2.6-3.8$ & $4.8-11.3$ & \\
\hline \multicolumn{5}{|l|}{ Mauzerall et al. (1998), field study } \\
\hline not identified & & & & 6.3 \\
\hline \multicolumn{5}{|l|}{ Singh et al. (2004), field study } \\
\hline not identified & $10.6-16.3$ & & $4.7-7.5$ & $3.8-4.1$ \\
\hline \multicolumn{5}{|c|}{ Andreae and Merlet (2001), review paper } \\
\hline Savanna and grassland & 18 & 1.2 & $1.9-4.6$ & \\
\hline extratropical forest & 16 & 1.2 & $2.3-2.7$ & \\
\hline agricultural residues & 19 & 1.3 & 3.3 & \\
\hline
\end{tabular}

1 These values have been calculated from the mean NEMRs in Table 1. E.g. NEMR $_{\text {methanol }}=1000 \times 19.0 / 498 \approx 38$

\subsection{Acetonitrile mixing ratios}

Mixing ratios and a statistical evaluation of acetonitrile are shown in Fig. 3. At the lowest two altitude levels significantly lower average than median mixing ratios were observed. From trajectory analysis (Traub et al., 2003) we can exclude that these air masses had been recently mixed with clean background air, so we conclude that the variability in the lowest $4 \mathrm{~km}$ of the troposphere was higher due to a stronger influence from biomass burning sources and uptake into the sea. Interestingly, the variability was also higher at altitudes above $11 \mathrm{~km}$. Again based on trajectory analysis we attribute this to fresh pollution advected from the convective monsoon regions in South Asia, where biofuel use is common (Scheeren et al., 2003). Figure 4 shows acetonitrile mixing ratios in the marine boundary layer and average sea surface temperature (SST) in August 2001 (Smith et al., 1996). The lowest acetonitrile mixing ratios were measured during a flight to the west of Sardinia. A potential reason for this can be found $\sim 200 \mathrm{~km}$ upwind, where acetonitrile was likely deposited into the sea over an extended zone of relatively cool, upwelling water. Similar observations were made by Warneke and de Gouw (2001) over the western Indian Ocean. From our data we do not see clear evidence for ocean uptake in other regions. Acetonitrile may still be taken up over the Eastern Mediterranean Sea but the uptake may be masked by continuous advection of biomass burning emissions. However, if acetonitrile is not biochemically removed in the seawater, ocean uptake (or release) of acetonitrile would basically be a function of sea surface temperature. In this case the ocean would only acts as reservoir and ace-

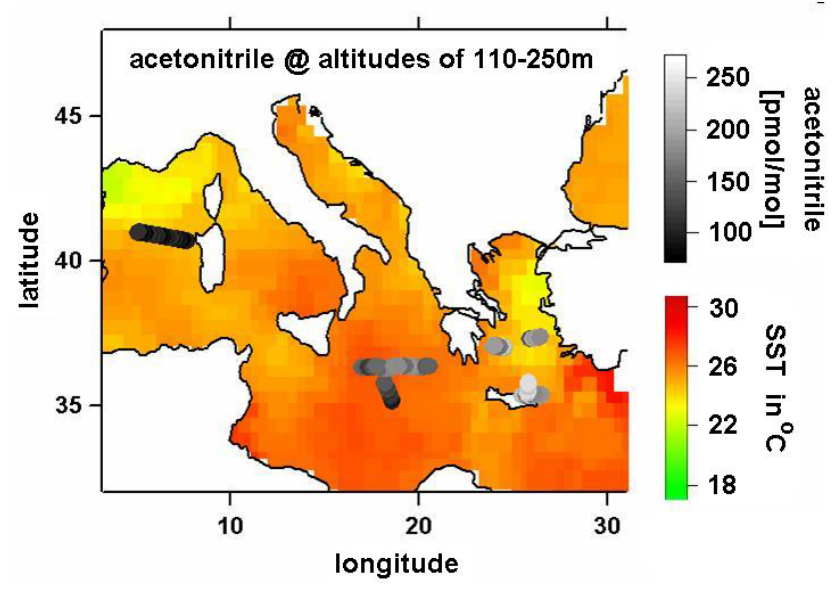

Fig. 4. Acetonitrile mixing ratios in the marine boundary layer, and the average sea surface temperature (SST) in August 2001 obtained from the NOAA/NASA Pathfinder Program (Smith et al., 2003).

tonitrile could be emitted from warmed up seawater as has been recently suggested by Sanhueza et al. (2004) to explain high acetonitrile concentrations over a Venezuelan savanna. This is also supported by results from a ship cruise across the tropical Atlantic; most time water concentrations of acetonitrile were found to be in equilibrium with air concentrations (Williams et al., 2004).

Based on the trajectory analysis by Traub et al. (2003) we split the dataset into 4 sub-sets (North Atlantic, Western Europe, Eastern Europe, and South Asia) according to the source region of the air masses; typical acetonitrile mixing 
Table 3. Typical mixing ratios ( $\mathrm{pmol} / \mathrm{mol}$ ) of acetonitrile in air from different source regions.

\begin{tabular}{cccccc}
\hline & All Data & North Atlantic $^{1}$ & Western Europe $^{1}$ & Eastern Europe $^{1}$ & South Asia $^{1}$ \\
\hline percentiles: & & & & & \\
$33 \%$ & 140 & 138 & 123 & 168 & 135 \\
$50 \%$ & 150 & 145 & 140 & 185 & 145 \\
$66 \%$ & 163 & 153 & 158 & 200 & 155 \\
Average & 156 & 147 & 141 & 186 & 147 \\
\hline
\end{tabular}

${ }^{1}$ Source regions according to Traub et al. (2003).

ratios are presented in Table 3. From this analysis we infer that average mixing ratios of $140-150 \mathrm{pmol} / \mathrm{mol}$ are prevalent throughout the troposphere. Singh et al. (2003) measured average acetonitrile mixing ratios of $149 \mathrm{pmol} / \mathrm{mol}$ at altitudes of $0-12 \mathrm{~km}$ over the Pacific Ocean (FebruaryApril, 2001), just several of months previously, and in excellent agreement with our results from the Eastern Mediterranean. Assuming an annual biomass burning source of $1.3 \pm 0.65 \mathrm{Tg}$ acetonitrile per year (Andreae and Merlet, 2001) and an average concentration of $150 \mathrm{pmol} / \mathrm{mol}$ a lifetime of $\sim 6 \pm 3$ months can be calculated; equal to the ratio obtained by dividing the tropospheric burden by the annual source. Considering a global mean HO concentration of $1.16 \times 10^{6}$ molecules $\mathrm{cm}^{-3}$ (Spivakovsky et al., 2000) and a reaction rate constant of $1.4 \times 10^{-14} \mathrm{~cm}^{3}$ molecules ${ }^{-1} \mathrm{~s}^{-1}$ (Atkinson et al., 1997, T=266 K) the photochemical lifetime of acetonitrile is $\sim 2$ years. Therefore, dry deposition to land and/or sea surfaces likely is the dominant sink for acetonitrile.

\section{Conclusions}

During the MINOS campaign ten biomass burning plumes were identified over the eastern Mediterranean. The NEMRs of acetone and methanol obtained from these plumes were higher than those observed in controlled experimental fires, whereas a lower production factor was measured for $\mathrm{CO}$. We infer secondary production of acetone and methanol in the biomass burning plumes, while $\mathrm{CO}$ is subject to net photochemically removal in the plumes.

Acetonitrile mixing ratios have been measured over the eastern Mediterranean Sea at altitudes of $0-13 \mathrm{~km}$. Given that current biomass burning inventories are correct, average concentrations are consistent with a lifetime of $\sim 6 \pm 3$ months. Therefore other sinks must dominate over photochemical degradation, most likely dry deposition over land and/or sea.

Acknowledgements. We thank two anonymous referees for constructive and high quality reviews. We gratefully acknowledge the support of the pilots and technicians of the DLR Falcon. We thank H. Fischer, B. Scheeren, and J. de Gouw for insightful comments on earlier manuscripts of this paper.
Edited by: W. T. Sturges

\section{References}

Andreae, M. O. and Merlet, P.: Emission of trace gases and aerosols from biomass burning, Global Biogeochem. Cyc., 15 (4), 955966, 2001.

Atkinson, R., Baulch, D. L., Cox, R. A., Hampson, R. F., Kerr, J. A., Rossi, M. J., and Troe, J.: Evaluated kinetic and photochemical data for atmospheric chemistry: Supplement VI - IUPAC subcommittee on gas kinetic data evaluation for atmospheric chemistry, J. Phys. Chem. Ref. Data, 26 (6), 1329-1499, 1997.

Bergamaschi, P., Hein, R., Brenninkmeijer, C. A. M., and Crutzen, P. J.: Inverse modeling of the global CO cycle 2. Inversion of C-13/C-12 and O-18/O-16 isotope ratios, J. Geophys. Res., 105 (D2), 1929-1945, 2000.

Berresheim, H., Plass-Dulmer, C., Elste, T., Mihalopoulos, N., and Rohrer, F.: $\mathrm{OH}$ in the coastal boundary layer of Crete during MINOS: Measurements and relationship with ozone photolysis, Atmos. Chem. Phys., 3, 639-649, 2003,

SRef-ID: 1680-7324/acp/2003-3-639.

Christian, T. J., Kleiss, B., Yokelson, R. J., Holzinger, R., Crutzen, P. J., Hao, W. M., Saharjo, B. H., and Ward, D. E.: Comprehensive laboratory measurements of biomass-burning emissions: 1 . Emissions from Indonesian, African, and other fuels, J. Geophys. Res., 108 (D23), doi:10.1029/2003JD003704, 2003.

de Gouw, J. A., Warneke, C., Holzinger, R., and Williams, J.: Inter-comparison Between Airborne Measurements of Methanol, Acetonitrile and Acetone Using Two Different Configured PTRMS Instruments, Int. J. Mass Spectrom., 239 (2-3), 129-137, doi:10.1016/j.ijms.2004.07.025, 2004.

Goode, J. G., Yokelson, R. J., Ward, D. E., Susott, R. A., Babbitt, R. E., Davies, M. A., and Hao, W. M.: Measurements of excess $\mathrm{O}-3, \mathrm{CO} 2, \mathrm{CO}, \mathrm{CH} 4, \mathrm{C} 2 \mathrm{H} 4, \mathrm{C} 2 \mathrm{H} 2, \mathrm{HCN}, \mathrm{NO}, \mathrm{NH} 3$, $\mathrm{HCOOH}, \mathrm{CH} 3 \mathrm{COOH}, \mathrm{HCHO}$, and $\mathrm{CH} 3 \mathrm{OH}$ in 1997 Alaskan biomass burning plumes by airborne fourier transform infrared spectroscopy (AFTIR), J. Geophys. Res., 105 (D17), 22 147$22166,2000$.

Hansel, A. and Wisthaler, A.: A method for real-time detection of PAN, PPN and MPAN in ambient air, Geophys. Res. Lett., 27 (6), 895-898, 2000.

Heikes, B. G., Chang, W. N., Pilson, M. E. Q., Swift, E., Singh, H. B., Guenther, A., Jacob, D. J., Field, B. D., Fall, R., Riemer, D., and Brand, L.: Atmospheric methanol budget and ocean implication, Global Biogeochem. Cyc., 16 (4), doi:10.1029/2002GB001895, 2002. 
Holzinger, R., Warneke, C., Hansel, A., Jordan, A., Lindinger, W., Scharffe, D. H., Schade, G., and Crutzen, P. J.: Biomass burning as a source of formaldehyde, acetaldehyde, methanol, acetone, acetonitrile, and hydrogen cyanide, Geophys. Res. Lett., 26 (8), 1161-1164, 1999.

Jacob, D. J., Field, B. D., Jin, E. M., Bey, I., Li, Q. B., Logan, J. A., Yantosca, R. M., and Singh, H. B.: Atmospheric budget of acetone, J. Geophys. Res., 107 (D10), doi:10.1029/2001JD000694, 2002.

Jost, C., Trentmann, R., Sprung, D., Andreae, M. O., McQuaid, J. B., and Barjat, H.: Trace gas chemistry in a young biomass burning plume over Namibia: Observations and model simulations, J. Geophys. Res., 108 (D13), doi:10.1029/2002JD002431, 2003.

Lawrence, M., Rasch, P. J., von Kuhlmann, R., Williams, J., Fischer, H., de Reus, M., Lelieveld, J., Crutzen, P. J., Schultz, M., Stier, P., Huntrieser, H., Heland, J., Stohl, A., Forster, C., Elbern, H., Jakobs, H., and Dickerson, R. R.: Global chemical weather forecasts for field campaign planning: predictions and observations of large-scale features during MINOS, CONTRACE, and INDOEX, Atmos. Chem. Phys., 3, 267-289, 2003,

SRef-ID: 1680-7324/acp/2003-3-267.

Lelieveld, J., Berresheim, H., Borrmann, S., Crutzen, P. J., Dentener, F. J., Fischer, H., Feichter, J., Flatau, P. J., Heland, J., Holzinger, R., Korrmann, R., Lawrence, M. G., Levin, Z., Markowicz, K. M., Mihalopoulos, N., Minikin, A., Ramanathan, V., de Reus, M., Roelofs, G.J., Scheeren, H. A., Sciare, J., Schlager, H., Schultz, M., Siegmund, P., Steil, B., Stephanou, E. G., Stier, P., Traub, M., Warneke, C., Williams, J., and Ziereis, H.: Global air pollution crossroads over the Mediterranean, Science, 298, 794-799, 2002.

Lindinger, W., Hansel, A., and Jordan, A.: On-line monitoring of volatile organic compounds at pptv levels by means of protontransfer-reaction mass spectrometry (PTR-MS) - Medical applications, food control and environmental research, Int. J. Mass Spectrom., 173 (3), 191-241, 1998.

Mauzerall, D. L., Logan, J. A., Jacob, D. J., Anderson, B. E., Blake, D. R., Bradshaw, J. D., Heikes, B., Sachse, G. W., Singh, H., and Talbot, B.: Photochemistry in biomass burning plumes and implications for tropospheric ozone over the tropical South Atlantic, J. Geophys. Res., 103 (D7), 8401-8423, 1998.

Salisbury, G., Williams, J., Holzinger, R., Gros, V., Mihalopoulos, N., Vrekoussis, M., Sarda-Esteve, R., Berresheim, H., von Kuhlmann, R., Lawrence, M., and Lelieveld, J.: Ground-based PTR-MS measurements of reactive organic compounds during the MINOS campaign in Crete, July-August 2001, Atmos. Chem. Phys., 3, 925-940, 2003,

SRef-ID: 1680-7324/acp/2003-3-925.

Sanhueza, E., Holzinger, R., Kleiss, B., Donoso, L., and Crutzen, P. J.: New insights in the global cycle of acetonitrile: release from the ocean and dry deposition in the tropical savanna of Venezuela, Atmos. Chem. Phys., 4, 275-280, 2004,

SRef-ID: 1680-7324/acp/2004-4-275.

Scheeren, H. A., Lelieveld, J., Roelofs, G. J., Williams, J., Fischer, H., de Reus, M., de Gouw, J. A., Warneke, C., Holzinger, R., Schlager, H., Klupfel, T., Bolder, M., van der Veen, C., and Lawrence, M.: The impact of monsoon outflow from India and Southeast Asia in the upper troposphere over the eastern Mediterranean, Atmos. Chem. Phys., 3, 1589-1608, 2003,

SRef-ID: 1680-7324/acp/2003-3-1589.
Simoneit, B. R. T.: Biomass burning - A review of organic tracers for smoke from incomplete combustion, Appl. Geochem., 17 (3), 129-162, 2002.

Singh, H., Salas, L., Herlth, D., Kolyer, R., Czech, E., Viezee, W., Li, Q. B., Jacob, D., Blake, D., Sachse, G., Harward, C. N., Fuelberg, H., Kiley, C. M., Zhao, Y. J., and Kondo, Y.: In-situ measurements of $\mathrm{HCN}$ and $\mathrm{CH} 3 \mathrm{CN}$ over the Oacific Ocean: Sources, Sinks, and budgets, J. Geophys. Res., 108 (D20), doi:10.1029/2002JD003006, 2003.

Singh, H. B., Kanakidou, M., Crutzen, P. J., and Jacob, D. J.: HighConcentrations and Photochemical Fate of Oxygenated Hydrocarbons in the Global Troposphere, Nature, 378 (6552), 50-54, 1995.

Singh, H. B., Salas, L. J., Chatfield, R. B., Czech, E., Fried, A., Walega, J., Evans, M. J., Field, B. D., Jacob, D. J., Blake, D., Heikes, B., Talbot, R., Sachse, G., Crawford, J. H., Avery, M. A., Sandholm, S., and Fuelberg, H.: Analysis of the atmospheric distribution, sources, and sinks of oxygenated volatile organic chemicals based on measurements over the Pacific during TRACE-P, J. Geophys. Res., 109, doi:10.1029/2003JD003883, 2004.

Smith, E., Vazquez, J., Tran, A., and Sumagaysay, R.: SatelliteDerived Sea Surface Temperature Data Available From the NOAA/NASA Pathfinder Program, http://www.agu.org/eos_ elec/95274e.html, American Geophysical Union, 2003.

Spivakovsky, C. M., Logan, J. A., Montzka, S. A., Balkanski, Y. J., Foreman-Fowler, M., Jones, D. B. A., Horowitz, L. W., Fusco, A. C., Brenninkmeijer, C. A. M., Prather, M. J., Wofsy, S. C., and McElroy, M. B.: Three-dimensional climatological distribution of tropospheric OH: Update and evaluation, J. Geophys. Res., 105 (D7), 8931-8980, 2000.

Talbot, R. W., Dibb, J. E., Scheuer, E. M., Blake, D. R., Blake, N. J., Gregory, G. L., Sachse, G. W., Bradshaw, J. D., Sandholm, S. T., and Singh, H. B.: Influence of biomass combustion emissions on the distribution of acidic trace gases over the southern $\mathrm{Pa}$ cific basin during austral springtime, J. Geophys. Res., 104 (D5), 5623-5634, 1999.

Traub, M., Fischer, H., de Reus, M., Kormann, R., Heland, J., Ziereis, H., Schlager, H., Holzinger, R., Williams, J., Warneke, C., de Gouw, J., and Lelieveld, J.: Chemical characteristics assigned to trajectory clusters during the MINOS campaign, Atmos. Chem. Phys., 3, 459-468, 2003,

SRef-ID: 1680-7324/acp/2003-3-459.

Warneke, C. and de Gouw, J. A.: Organic trace gas composition of the marine boundary layer over the northwest Indian Ocean in April 2000, Atmos. Environ., 35 (34), 5923-5933, 2001.

Wienhold, F. G., Fischer, H., Hoor, P., Wagner, V., Konigstedt, R., Harris, G. W., Anders, J., Grisar, R., Knothe, M., Riedel, W. J., Lubken, F. J., and Schilling, T.: TRISTAR - a tracer in situ TDLAS for atmospheric research, Appl. Phys. B-Lasers and Optics, 67 (4), 411-417, 1998.

Williams, J., Poeschl, U., Crutzen, P. J., Hansel, A., Holzinger, R., Warneke, C., Lindinger, W., and Lelieveld, J.: An atmospheric chemistry interpretation of mass scans obtained from a proton transfer mass spectrometer flown over the tropical rainforest of Surinam, J. Atmos. Chem., 38 (2), 133-166, 2001.

Williams, J., Roberts, J. M., Bertman, S. B., Stroud, C. A., Fehsenfeld, F. C., Baumann, K., Buhr, M. P., Knapp, K., Murphy, P. C., Nowick, M., and Williams, E. J.: A method for the airborne 
measurement of PAN, PPN, and MPAN, J. Geophys. Res., 105 (D23), 28 943-28 960, 2000.

Williams, J., Holzinger, R., Gros, V., Xu, X., Atlas, E., and Wallace, D. W. R.: Measurements of organic species in air and seawater from the tropical Atlantic, Geophys. Res. Lett., 31, doi:10.1029/2004GL020012, 2004.
Yokelson, R. J., Goode, J. G., Ward, D. E., Susott, R. A., Babbitt, R. E., Wade, D. D., Bertschi, I., Griffith, D. W. T., and Hao, W. M.: Emissions of formaldehyde, acetic acid, methanol, and other trace gases from biomass fires in North Carolina measured by airborne Fourier transform infrared spectroscopy, J. Geophys. Res., 104 (D23), 30 109-30 125, 1999. 